Archives of Environmental Contamination and Toxicology

January 2009, Volume 56 (1) : Pages 39-51

http://dx.doi.org/10.1007/s00244-008-9164-z

(c) 2008 Springer. Part of Springer Science+Business

Media

The original publication is available at http://www.springerlink.com
Archimer, archive institutionnelle de l'Ifremer http://www.ifremer.fr/docelec/

\title{
Responses of Planktonic Microorganisms from Tropical Reservoirs to Paraquat and Deltamethrin Exposure
}

\author{
Christophe Leboulanger ${ }^{1,{ }^{*}}$, Marc Bouvy ${ }^{1}$, Marc Pagano ${ }^{2}$, Rose-Aimée Dufour ${ }^{1,3}$, Patrice Got $^{3}$ and \\ Philippe Cecchi ${ }^{1,4}$
}

${ }^{1}$ IRD UR 167 Cyroco, c/o UMR 5119 CNRS Ifremer Université Montpellier II, CC093, 34095 Montpellier cedex 5, France

${ }^{2}$ IRD UR 167 Cyroco, Centre Océanologique de Marseille, rue de la Batterie des Lions, 13007 Marseille, France

${ }^{3}$ UMR 5119 CNRS Ifremer Université Montpellier II, CC093, 34095 Montpellier cedex 5, France

${ }^{4}$ IRD UR 167 Cyroco, 9 56, avenue Agostino Neto, BP 182, Ouagadougou 01, Burkina Faso

*: Corresponding author : Christophe Leboulanger, email address : leboulan@mpl.ird.fr

\begin{abstract}
:
This study focused on the effects of two pesticides, paraquat (herbicide) and deltamethrin (insecticide), which are two common molecules used intensively in Burkina Faso. Natural bacterial populations, phytoplankton cultures (one cyanobacterium, Cylindrospermopsis raciborskii, and one chlorophycea, Monoraphidium sp.), and two species of zooplankton (Diaphanosoma excisum and Moina micrura) were isolated from aquatic communities and were used as biological targets in the experimental protocols. Paraquat was moderately toxic to bacteria and phytoplankton, whereas deltamethrin was significantly toxic only to the zooplankton species. Paradoxically, the chlorophycea Monoraphidium sp. exhibited a significant increase of in vitro fluorescence after $48 \mathrm{~h}$ at the highest doses. Preliminary tests were also performed from natural water extract of the main drinking water supply of the country (Loumbila Reservoir) by using solid-phase extraction. Obviously, the natural extract proved to be toxic to the same biological targets. Despite the absence of any determination of pesticides in the natural extract, the question of contamination and toxicity of these waters affects concerns about the safety of water supply and the effect of human pressure on the dynamics of planktonic communities of freshwater reservoirs in arid regions of western Africa.
\end{abstract}

Keywords: paraquat, deltamethrin, planktonic organisms, reservoirs, West Africa 


\section{Introduction}

The many ecological disturbances in aquatic ecosystems linked to anthropogenic pressures (e.g., loss of biodiversity, harmful algal blooms, hypoxia, disease, and decline in fisheries) have been well documented (Conley 1999; Paerl et al. 2003). In freshwater ecosystems, deterioration of water quality might be attributable to excess nutrients, leading to excessive primary production or eutrophication (Paerl 1997). Among the aquatic biota, microorganisms are generally highly sensitive and their dynamics can be seriously affected by environmental perturbation. Bacteria, phytoplankton, and zooplankton have fast growth rates and, therefore, can provide meaningful and quantifiable indicators of ecological change on short timescales (Paerl et al. 2003). On the other hand, these organisms can respond to low levels of pollutants such as pesticides, which constitute a major anthropogenic stress on natural communities (Relyea 2005).

The indiscriminate use of pesticides for chemical control of pests might strongly disturb biological functioning in aquatic systems (Lürling and Roessink 2006; Relyea 2005). Experiments to understand the real effects of pesticides on a broad range of taxa 
seem to be the best way of obtaining information about patterns of diversity and productivity in aquatic systems subjected to pesticides. While phytoplankton and zooplankton have often been used as test organisms to follow the effects of pesticides in aquatic systems, responses of natural bacterial communities have rarely been studied for this purpose in aquatic systems, unlike in terrestrial systems (e.g. Nicholson and Hirsch 1998). Due to their rapid growth rate, bacteria could exhibit rapid functional recovery after toxic exposure, resulting in a different community structure (Knapp et al. 2005). Furthermore, needs for assessment of tropical species sensitivity, compare to enhanced knowledge on temperate organisms, have been claimed by several authors (e.g. Wiktelius et al. 1999, Chapman et al. 2006)

Scarcity of water resources and continuous degradation of quality are current hazards for human beings in the West Africa Sahelian zone. Among the multiple sources of degradation, pollution can be directly linked to human activities (e.g. intensified agriculture and urban expansion) in an area where the environmental policy is generally weak. In Burkina Faso, thousands of reservoirs of various sizes have been created in the last 50 years to cope with the seasonal variations in rainfall and increasing demand. Very little data is available on the use of pesticides in the Nakambé basin (formerly White Volta), the main central basin in Burkina Faso, although most of the reservoirs lie in this region with a high water demand for human purposes. The only semi-official data available has been provided by the AFAMIN resource (www.afamin.net, discontinued to date) that listed the compounds authorized for use in agriculture in Western Africa for the 20022005 period. Thus, a wide range of products appears to be available in Burkina Faso for controlling insects and pests, but in most cases no information about their composition is given by the local suppliers. Nevertheless, among the compounds that are listed, highly toxic chemicals such as thiram, paraquat, cypermethrin, deltamethrin, etc. are found in various forms. Contamination of similar ecosystems, such as the one reported on the bordering Ghana (Osafo and Frempong 1998, Ntow 2001, Ntow 2005), suggests that impact on surface waters is likely to occur in Burkina Faso.

Even when the target compounds have been identified and quantified, their toxicity to aquatic life is usually unpredictable owing to the lack of data on tropical ecosystems and organisms (Wiktelius et al. 1999). This problem may be resolved by using bioassays on water concentrates to give a direct functional response to the pollutant on a given organism (or community). Man-made chemicals and their metabolites can be concentrated using solid-phase extraction (Wilhelm et al. 1996, Baun et al. 1998, Christensen et al. 2006, Xue et al. 2006) to achieve toxic levels that are high enough to have a significant effect on the target organisms in experiments.

This study aimed at evaluating the toxic effects of two pure pesticides (an herbicide, paraquat, and an insecticide, deltamethrin) on tropical planktonic organisms. Paraquat targets the PSI system of photosynthetic organisms and leads to intracellular oxidative stress, whereas deltamethrin prevent the nerves sodium channels from closing in arthropods, resulting in continuous nerve impulse transmission. A suspected action of paraquat on muscular system of zooplankton have been documented (Gagneten 2002), although no mechanistic explanation for direct effects of deltamethrin on phytoplankton or bacterioplankton have been proposed to date. The selected test organisms were isolated from two reservoirs on the Nakambé River for bacteria communities and zooplankton species. Cultures of phytoplankton species isolated from other West Africa reservoirs (Lake Guiers and Dakar Bango Reservoir, North Senegal) were also used. This first toxicological report in West Africa was completed by preliminary experiments on natural water toxic potential (the Loumbila reservoir, dedicated to drinking water supply of the Ouagadougou city) using solid-phase extraction (SPE) cartridges. 


\section{Material and methods}

\section{Sampling and collection of target organisms}

This study was focused on three reservoirs located in Nakambé basin in central Burkina Faso, Western Africa. The environmental parameters of each reservoir during the survey are listed in Table 1. Standard methodologies were applied for analysing the environmental parameters (see details in Bouvy et al. 2006).

Two reservoirs were sampled in March, 2005, for isolation of test organisms, Koubri $\left(12^{\circ} 12^{\prime} 59^{\prime \prime} \mathrm{N}\right.$; $\left.1^{\circ} 19^{\prime} 4^{\prime \prime} \mathrm{W}\right)$ and Bam $\left(13^{\circ} 19^{\prime} 53^{\prime} \mathrm{N} ; 1^{\circ} 30^{\prime} 50^{\prime \prime} \mathrm{W}\right)$. These reservoirs were created by damming natural permanent wetlands, resulting in permanent water bodies. No strong anthropogenic pressure, as effluent sewage or industrial discharge, was observed in situ, and pollution if any should be diffuse. Bacterial communities were sampled from these two reservoirs. Zooplanktonic cladoceran species (Moina micrura and Diaphanosoma excisum) were collected from the Koubri reservoir, using a $200 \mu \mathrm{m}$ mesh net. Phytoplankton cultures were used for testing photosynthetic organisms: a heterocystous cyanobacterium (Cylindrospermopsis raciborskii PMC 118-02) from Lake Guiers, Senegal (Berger et al. 2006), and a chlorophycea (Monoraphidium sp. PMC BF6) from the Bam reservoir, Burkina Faso. Loumbila reservoir $\left(12^{\circ} 29^{\prime} 38^{\prime \prime} \mathrm{N} ; 1^{\circ} 24^{\prime} 8^{\prime \prime} \mathrm{W}\right)$ is located in an area of intensive farming, with a strong eutrophication process with high load of suspended material and orthophosphate concentrations (Table 1). This reservoir which is also the main drinking water for the capital, Ouagadougou, was sampled for solid phase extraction (SPE cartridges Oasis ${ }^{\circledR}$ HLB, Waters Corp.) to test the potential toxic effect of the water concentrate (Baun et al. 1998). For all bioassays, sub-surface water samples were collected using acid-washed polyethylene bottles and then immediately transported to a temporary field laboratory near Koubri.

\section{Pure pesticide solutions}

Analytical grade deltamethrin ((S)- $\alpha$-cyano-3-phenoxybenzyl-(1R,3R)-3-(2,2-dibromovinyl)-2,2-dimethyl cyclopropane carboxylate, a synthetic pyrethroid in use for insect control) and paraquat (1,1'-dimethyl-4,4'bipyridinium, a systemic herbicide) were purchased from Sigma-Aldrich. These compounds were chosen as model pesticides, among commercially available ones in Burkina Faso (paraquat as Gramoxone ${ }^{\circledR}$ or Calloxone $\left(\right.$ ), and deltamethrin personally observed on sale at Koubri local market (as K-othrine ${ }^{\circledR}$ ). Five different concentrations and one control solution were prepared by serial dilution (steps of $10^{1 / 2}$ ) of an initial methanol solution (Table 2), and then stored for few days at $-20^{\circ} \mathrm{C}$. Working solutions were made by diluting the methanol solutions in pure water in acid washed $20 \mathrm{~mL}$ glass scintillation vials and stored in the dark below $4^{\circ} \mathrm{C}$ for less than three days. All concentrations stated further are nominal, and all tests were performed in triplicate with solvent controls.

\section{Solid phase extraction from natural samples}

Water sample of $5 \mathrm{~L}$ was taken from surface in Loumbila reservoir in an acid-cleaned polyethylene bag, and immediately processed. Water was filtered through $0.8 / 0.2 \mu \mathrm{m}$ porosity filter cartridge (AcroPak 500, Pall Corp.) at a flow rate of $2 \mathrm{~L} / \mathrm{h}$ and immediately treated by solid phase extraction (SPE). The filtrate was acidified to $\mathrm{pH} 4$ using concentrated HCl. An Oasis HLB $500 \mathrm{mg}$ cartridges (Waters Corp., Milford, Massachusetts, USA) was conditioned using $5 \mathrm{~mL} \mathrm{MeOH}$ :water $(60: 40 \mathrm{v} / \mathrm{v})$. The cartridge model was chosen as the most generalist one according to the manufacturer's manual, to ensure extraction of as many compounds as possible. No specific extraction for paraquat (e.g. with MCX cartridges, Nunez et al. 2000) and deltamethrin (e.g. with C18 cartridges, Hengel et al. 1997) was intended, due to laboratory limitations on site. The acidified filtrate (1 to $4 \mathrm{~L})$ was passed gently through the cartridge using a peristaltic pump (flow around $1 \mathrm{~L} / \mathrm{h}$ ). The cartridge was then rinsed with $10 \mathrm{~mL} \mathrm{MeOH}$ :water $(5: 95 \mathrm{v} / \mathrm{v})$, and the compounds retained were eluted by gently passing $10 \mathrm{~mL}$ of analytical grade methanol using a syringe. The methanol extract was collected and evaporated in moving air at room temperature (between 25 and $30^{\circ} \mathrm{C}$ ). The final volume of extract was adjusted to $2 \mathrm{~mL}$ to give a concentration factor close to 4000 depending on the initial volume of water (which was determined by the filtering capacity of the system within few hours, and the particulate matter in the sample). Five different concentrations and one control solution were prepared by serial dilution (steps of $10^{1 / 2}$ ) of the initial methanol solution (Table 2). Working solutions were made by diluting the methanol solutions in pure water in acid washed $20 \mathrm{ml}$ glass scintillation vials. For all toxicity tests, the concentrations of the reservoir extracts were expressed as volume / volume ( $\mathrm{mL} / \mathrm{L}$ or $\mathrm{L} / \mathrm{L}$ depending on the case); a value of $1 \mathrm{~L} / \mathrm{L}$ means a concentration equivalent to that in the original environment (Baun et al. 1998). 


\section{Bioassays}

\section{Bacterial bioassay}

The purpose of this section was to test the sensitivity of complex bacterial communities. Isolation of bacterial strains, although possible, was not included since isolation media are prone to exert a strong selection among initial diversity of bacterioplankton. Sub-surface water samples from Koubri and Bam reservoirs were processed within 1 hour after collection. Bacterial populations were obtained by filtration through $1 \mu \mathrm{m}$-Nuclepore polycarbonate filters with a sterilized Nalgene filtering flask (vacuum $<2 \mathrm{~cm} \mathrm{Hg}$ ) to remove all bacterial grazers and phytoplankton. Three different concentrations and the control solution were assayed for pure pesticides. Only one concentration $(6.1 \mathrm{~L} / \mathrm{L})$ was tested for the concentrated water extract of Loumbila. All bioassays were based on bacterial growth measurements using a dilution technique. The ratio of original to filtered samples was $25: 75(\mathrm{v} / \mathrm{v})$ using $0.22 \mu \mathrm{m}$ filtered water from the same reservoir. Diluted bacterioplankton were transferred into acid-washed $500 \mathrm{~mL}$ polycarbonate bottles. All treatments were performed in duplicate and the bottles were incubated in the reservoir at a depth of $1 \mathrm{~m}$ to mimic the in situ environmental conditions, especially temperature.

Subsamples were removed for bacterial analysis after incubation for 12 hours and 24 hours. Bacterial abundance was determined by epifluorescence microscopy after staining with DAPI fluorochrome (Porter and Feig 1980). Analysis by flow cytometry of the bacterial community were performed using SYBR-green I (Molecular Probes) bacterial cell stain using the method described by Marie et al. (1997). Subsamples were fixed with buffered formalin and immediately stored in liquid nitrogen until analysis as described by Bouvy et al. (2004), and then treated as reported by Troussellier et al. (1999). Cultivable heterotrophic bacterial counts were performed by plating $100 \mu \mathrm{L}$ of untreated water or decimal dilutions onto nutrient agar (Tryptic Soy Agar, TSA, AES laboratory). Bacterial activity was estimated using (methyl- ${ }^{3} \mathrm{H}$ ) thymidine incorporation into cold trichloracetic acid (TCA) precipitate as described by Bouvy et al. (2004).

The pesticide molecules and the natural extract were considered to be toxic after 12 and 24 hours of treatment if significant differences were obtained in terms of abundance and thymidine incorporation. The nonparametric Kruskal-Wallis test was used for analyzing significant differences in biological responses.

\section{Algal bioassay}

Phytoplankton cultures were used as model organisms for planktonic photoautotrophs. Use of natural phytoplankton communities locally sampled was precluded by the high level of suspended material in reservoirs, which would have interfered with the chosen measuring protocol. Two species were selected among few available, for their tropical origin (West Africa) and known occurrence in the local area (unpublished data), the cyanobacteria Cylindrospermopsis raciborskii and the chlorophyte Monoraphidium sp.. In vivo fluorescence (IVF) has been chosen as endpoint for measuring toxicity effects on microalgae, as it encompasses both modification of photosynthetic metabolism in short term experiments (Seguin et al. 2002). The algal strains were cultured on Z8X for the cyanobacteria and Z8 media for the chlorophyceae (Briand et al. 2004), kept in a thermostatic chamber $\left(28^{\circ} \mathrm{C}\right)$ and illuminated using fluorescence tubes providing light intensity of about 100 $\mu \mathrm{E} / \mathrm{m} / \mathrm{s}$, with a 12 hour light / 12 hour dark cycle. Cultures were renewed each week to ensure that cells were in exponential growth when the assays were carried out.

Cultures of each strain ( $1 \mathrm{~mL}$ inoculum added to $5 \mathrm{~mL}$ fresh media) were placed in $10 \mathrm{~mL}$ borosilicate glass tubes and received five concentrations of contaminant and a pure control. All samples were run in triplicates. Tubes were monitored non-destructively for two days using in vivo fluorescence (IVF) of chlorophyll $a$ (Leboulanger et al. 2006). The tubes were dark adapted for 20 minutes before measuring the IVF using a TD 700 fluorimeter (Turner Designs). All the results were expressed as a percentage of control IVF after zero correction. Toxicity was considered to be positive after $6,18,24$ and 48 hours of exposure if significant changes in IVF values were obtained, either decreasing or increasing relative to the control (Seguin et al. 2002). The results were analyzed using ANOVA and post hoc Tukey's pairwise comparison (Past freeware, Hammer and Harper 2005).

\section{Zooplankton bioassay}

Two zooplanktonic cladoceran species (Moina micrura and Diaphanosoma excisum) were collected using a 200 $\mu \mathrm{m}$ mesh net. The animals were acclimated to laboratory conditions in $5 \mathrm{~L}$ buckets for several hours. The ovigenous females of the two species were identified and separated using a binocular microscope. The animals were then raised for two weeks in $1 \mathrm{~L}$ bottles, filled with Koubri reservoir water initially filtered through a 30 $\mu \mathrm{m}$ mesh to remove other grazers. Each day, the filtered water was changed, and the zooplankton cultures were diluted in order to ensure that reproduction stayed clonal under non-limiting conditions. 
For acute toxicity experiment, newborn juveniles (less than 24 hours old) were collected from the culture and put into $40 \mathrm{~mL}$ flasks (four replicates per treatment) filled with $10 \mathrm{~mL}$ of the medium (5 individuals per flask). The medium was made using $30 \mu \mathrm{m}$ filtered Koubri reservoir water with $125 \mu \mathrm{L}$ of the pesticide or concentrated extract. The flasks were checked after incubating for 24 hours and 48 hours. Each time, motionless animals were considered to be dead and removed from the flasks, and eventual recovery was not recorded.

For chronic toxicity assessment, newborn juveniles were collected and put into $40 \mathrm{~mL}$ flasks (four replicates per treatment) filled with $30 \mathrm{~mL}$ of the medium ( 3 individuals per flask). Incubation lasted five days, corresponding to the time taken to reach an optimal density just before the apparition of sexual forms and population collapse (Pagano et al. 2000). The flasks were checked each day by counting the animals in a $10 \mathrm{~mL}$ subsample of the homogenized culture using a binocular microscope. After counting, each living individual was collected and put back in the test vessel and volume was made up to $30 \mathrm{~mL}$ by adding $10 \mathrm{~mL}$ of freshly prepared medium with the same concentration of toxicant. At the end of the experiments, all the animals (dead or alive) were counted. The population growth rate was calculated from the exponential growth phase between the beginning and the end of incubation time. The results were analyzed using ANOVA and post hoc Tukey's pairwise comparison to test the growth rate differences between concentrations.

\section{Results}

\section{Environmental context of the reservoirs studied}

Values of the main physical and chemical features of each reservoir are presented in Table 1. All the reservoirs are shallow (mean depth $230 \mathrm{~cm}$ ) and very turbid (Secchi depth less than $63 \mathrm{~cm}$ ). A high density of suspended matter (sestonic weight) was observed in the reservoirs, especially in the Loumbila reservoir $(58.4 \mathrm{mg} / \mathrm{L})$. Conductivity was generally low, between 61.9 and $85.8 \mu \mathrm{S} / \mathrm{cm}, \mathrm{pH}$ values were between 6.82 and 7.12 , and surface temperature varied from 27.3 to $30.4^{\circ} \mathrm{C}$. Dissolved oxygen concentrations at the surface were close to saturation. The dissolved ammonium concentrations varied between 0.7 and $3.5 \mu$ mole/L. Dissolved orthophosphate concentrations showed lower values in Koubri and the highest in Loumbila $(1.42 \mu$ mole/L). Chlorophyll $a$ concentrations showed large variations between reservoirs, between 9.6 and $18.6 \mu \mathrm{g} / \mathrm{L}$.

\section{Effects of paraquat and deltamethrin on planktonic microorganisms}

\section{Effects on natural bacterial populations}

For each pesticide tested on bacterial communities isolated from Koubri reservoir, three concentrations and the control solution were used. Paraquat did not seem to have any significant effect on the total abundance of the bacteria (Fig. 1A) at any concentration (Mann-Whitney test, $p=0.343$ ). On the contrary, deltamethrin caused a significant decrease of total bacterial abundance after 12 and 24 hours $(\mathrm{p}=0.029)$ with $76(12 \mathrm{~h})$ and $65 \%(24 \mathrm{~h})$ of control value for $4.4 \mu \mathrm{g} / \mathrm{L}$ contamination, and $77(12 \mathrm{~h})$ and $70 \%(24 \mathrm{~h})$ of control value for $44.2 \mu \mathrm{g} / \mathrm{L}$. A partial recovery was noticed, showing enhancement of bacterial growth, for $442 \mu \mathrm{g} / \mathrm{L}$ deltamethrin, with an increase from 44 to $57 \%$ of control value between 12 and $24 \mathrm{~h}$ (Fig. 1B). However, the effects were significantly different for other bacterial descriptors, which are considered to be realistic physiological indicators of bacterial growth. In the present study, activity expressed as thymidine incorporation was inhibited (definitively with paraquat, transitory with deltamethrin) whereas cell density was not affected. Paraquat had a significant effect on cultivable bacteria, especially at the lowest concentration $(5.7 \mu \mathrm{g} / \mathrm{L})$, which resulted in $31 \%$ of control value after 24 hours (Fig. 1C), whereas 57.7 and $577 \mu \mathrm{g} / \mathrm{L}$ paraquat resulted in CFU/mL accounting for 42 and $61 \%$ of control after $24 \mathrm{~h}$ respectively. A negative effect on bacterial activity $\left({ }^{3} \mathrm{H}\right.$-thymidine incorporation), with no significant recovery after 24 hours at any concentration (Fig. 1E) was also observed with paraquat, activity decreasing dramatically down to $4 \%$ of control value for $577 \mu \mathrm{g} / \mathrm{L}$ paraquat after $24 \mathrm{~h}$ exposure. Deltamethrin did not show any significant difference in cultivable bacteria compared to the control (Fig. 1D); however, the bacterial activity was reduced after 12 hours at increasing concentrations showing a dose-dependent negative effect down to $30 \%$ of control activity for the sample exposed to $442 \mu \mathrm{g} / \mathrm{L}$ deltamethrin. In this latter case, after 24 hours, all deltamethrin concentrations resulted in the same ${ }^{3} \mathrm{H}$-thymidine incorporation rate, reduced by $30 \%$ with respect to the control (Fig. 1F). 


\section{Effects on cultured microalgae}

The herbicide paraquat was shown to be toxic to the two algal strains tested, based on in vivo fluorescence measurements. After 6 hours of exposure, IVF from Monoraphidium sp. and Cylindrospermopsis raciborskii cultures increased significantly $(200$ and $115 \%$ of control, respectively) at paraquat concentrations of $57 \mu \mathrm{g} / \mathrm{L}$ and higher (Fig. 2A). The patterns for the two species differed after 40 hours exposure, with the Monoraphidium sp. apparently recovering (Fig. 2B) except at the highest paraquat concentration $(577 \mu \mathrm{g} / \mathrm{L})$ where IVF was $238 \%$ of control value. However, C. raciborskii cultures exposed to 57 and $183 \mu \mathrm{g} / \mathrm{L}$ showed a significant decrease of IVF (70 and $35 \%$ of control value respectively) compared to the control, while the highest concentrations induced an increase up to $148 \%$ relative to the control (Fig. 2B), together with an apparent bleaching of the cultures.

The insecticide deltamethrin did not have any effect on any of the cultures for the first day of incubation (Fig. 2C). However, at the highest concentration $(443 \mu \mathrm{g} / \mathrm{L})$ there was a significant increase $(\mathrm{p}<0.01 \%)$ in IVF in Monoraphidium sp. cultures (220\% of control value) after 40 hours exposure (Fig. 2D).

\section{Effects on zooplankton cultures}

In the acute toxicity tests (short time effect), a dose-effect relationship on zooplankton mortality was noticed for paraquat for the two species, Diaphanosoma excisum (Fig. 3A) with a LOEC of $57.7 \mu \mathrm{g} / \mathrm{L}$, and Moina micrura (Fig. 3B) with a LOEC of $577 \mu \mathrm{g} / \mathrm{L}$. On the other hand, deltamethrin was highly toxic to both these species (Fig. 3C and D) and all individuals died at the lowest concentration of toxicant $(4.4 \mu \mathrm{g} / \mathrm{L})$ so that no dose-response relationship could be determined for deltamethrin. Paraquat herbicide was more toxic to D. excisum than to M. micrura. After only 24 hours of exposure, the third concentration $(57.7 \mu \mathrm{g} / \mathrm{L})$ was lethal for more than half of the individuals of $D$. excisum, whereas no significant effect was observed for $M$. micrura for all the paraquat concentrations tested at this moment. Nevertheless for this latter species, all individuals finally died after 48 hours incubation at $578 \mu \mathrm{g} / \mathrm{L}$ paraquat, which was the only concentration that gave results significantly different from the control.

In the chronic toxicity tests with a long time effect, lower concentrations were used (up to $2.21 \mu \mathrm{g} / \mathrm{L}$ ); paraquat did not have any significant effect on M. micrura $(\mathrm{F}=3.13$; Fig. 3E) although lower population growth rates were observed at the higher concentrations of paraquat. Deltamethrin had a significant effect on $M$. micrura $(\mathrm{F}=240.2)$ with a noticeable reduction of the population growth rate at $2.21 \mu \mathrm{g} / \mathrm{L}$ (Fig. 3F).

\section{Effects of concentrated water extract from Loumbila on planktonic microorganisms}

The final concentration of the water extract from Loumbila was close to 6.1 compared to the natural concentration. The test solution preparation (dilution in aqueous medium) diluted the initial concentrates and the effective maximum concentration applied to the organisms was $2.04 \mathrm{~L} / \mathrm{L}$ (i.e. the used concentration of Loumbila extract in the most concentrated test conditions was twice the natural concentration).

\section{Effects on bacterial populations}

The bacterial populations tested were isolated from two reservoirs (Koubri and Bam) characterized by their trophic status (Table 1). Responses of growth rates obtained after 24 hours exposure were similar for the two bacterial communities, with the water extracts from Loumbila reservoir having an obvious negative effect (Fig. 4): total (Fig. 4A, D) and cultivable (Fig. 4B, E) bacteria abundance and bacterial activity (from ${ }^{3} \mathrm{H}$-thymidine incorporation, Fig. $4 \mathrm{C}, \mathrm{F}$ ) were lower in the concentrated extract than in the control solution. Abundance of cultivable bacteria for the two communities appeared to increase after 24 hours exposure compared to the low response obtained after 12 hours exposure. The results obtained by flow cytometry showed a separation into 3 groups (A1, A2, A3) for bacterial populations isolated from Koubri reservoir, that differed in the increase in DNA content level (dye fluorescence intensity, FL1) and apparent size (scatter values SSC) (Fig. 5A). With the water extracts from the 
Loumbila reservoir, the cytograms, representing the FL1 and SSC distributions for the bacterial populations, were very different after 12 hours and 24 hours exposure. After 12 hours treatment, the three initial groups disappeared completely, leaving a single population B1 (Fig. 5B). This comprised small cells with low nucleic acid content. After 24 hours exposure, cytometric analysis revealed a separation into two bacterial groups, C1 and C2, with different FL1 and SCC results compared with the control (Fig. 5C).

\section{Effects on cultured microalgae}

IVF measurements on $C$. raciborskii cultures were made after 6 and 24 hours incubation with concentrated water extracts (Fig. 6A and B respectively). Changes in IVF values of the C. raciborskii cultures were observed both after 6 and 24 hours incubation with serial dilutions of the extract. The IVF significantly decreased in the lower concentrations, then increased significantly compared to the control for higher concentrations $(2041 \mathrm{~mL} / \mathrm{L})$. The IVF significantly decreased at lower concentrations ( $\mathrm{p}<0.01$ for $645 \mathrm{~mL} / \mathrm{L})$ but reached levels up to $150 \%$ of the control for the highest concentration $(2040 \mathrm{~mL} / \mathrm{L})$. The lowest observable effect concentration (LOEC, the lowest concentrations used in the test that caused significant changes compared with the control) was 645 $\mathrm{mL} / \mathrm{L}$ for the concentrated extracts (two thirds of the normal concentration).

\section{Effect on zooplankton cultures}

In the acute toxicity test, the concentrated water extract had a dramatic effect on the two zooplankton species, with a 100\% mortality rate after 24 hours exposure at all concentrations (Fig. 7A, B). In the chronic toxicity tests, the effect on population growth rates was significant for the extract: at concentrations of 12.8 and $32 \mathrm{~mL} / \mathrm{L}$, the extracts resulted in a negative population growth rate indicating a long-term mortality (Fig. 7C).

\section{Discussion}

The results of this study indicate that pesticides can have short-time toxic effects on the planktonic microorganisms of tropical freshwaters. The lag between inoculation in test vessels and appearance of significant effects ranged between 6 and $48 \mathrm{~h}$, depending on the molecule and the test organisms. This was supposed to avoid major bias due to the relative fugacity of the two pesticides, which are know to rapidly adsorb on suspended particulate material and glassware. As previously reported (Wong 2000, Relyea 2005), the effects of the herbicide and the insecticide on the microorganisms tested were very different, as illustrated by the LOECs (Table 3). In our study, the herbicide paraquat was toxic to both phytoplankton species tested, whereas the insecticide deltamethrin was highly toxic to zooplankton, in accordance with their known biochemical modes of action (Lahr et al. 2000). Deltamethrin inhibits selectively the acetylcholine esterase of insects, whereas paraquat generates oxygen radicals by diverting electron flow in photosystem I of plants. Paraquat toxicity has been reported for the cyanobacterium Microcystis aeruginosa isolated from Florida, and the toxicity resulted in an increase in synthesis and release of microcystin in surrounding waters (Ross et al. 2006). The LOEC reported for paraquat in the present study $(57 \mu \mathrm{g} / \mathrm{L})$ lies in the range observed with standard phytoplankton organisms; for example, Sáenz et al. (1997) reported LOEC of 0.05 to $0.8 \mathrm{mg} / \mathrm{L}$ for three strains of Scenedesmus, $0.05 \mathrm{mg} / \mathrm{L}$, and $0.2 \mathrm{mg} / \mathrm{L}$ for Chlorella vulgaris and Selenastrum capricornutum respectively. Differences between chlorophytes and cyanobacteria should however be linked to the respective density of PSII and PSI in photosynthetic apparatus, that constitutionally differs in each taxa. On the other hand, unexpected effects were noticed for high level contamination by paraquat on zooplankton, as previously reported by Gagneten (2002) or Alberdi et al. (1996) with EC50 of 2.57 and $4.55 \mathrm{mg} / \mathrm{L}$ for two Daphnia species. Our results exhibited significant zooplankton mortality at $57.7 \mu \mathrm{g} / \mathrm{L}$, and death of all organisms at $577 \mu \mathrm{g} / \mathrm{L}$ after $48 \mathrm{~h}$ of exposure; this is contrasting with the results of Perschbacher and Ludwig (2004), who applied aerially paraquat in microcosms at a concentration of $120 \mu \mathrm{g} / \mathrm{L}$, resulting in no effect on zooplankton. Paraquat, as a quaternary amine, is rarely considered to be toxic for animals as this is not linked to its primary herbicide function.

The toxicity of deltamethrin to the phytoplankton Monoraphidium sp. was unexpected, and the concentration required for adverse effects (LOEC of $442.5 \mu \mathrm{g} / \mathrm{L}$ ) was extremely high compared with 
the LOEC for zooplankton (the lethal dose was $4.42 \mu \mathrm{g} / \mathrm{L}$, chronic LOEC was $2.21 \mu \mathrm{g} / \mathrm{L}$, see Table 3). The precise mechanism of deltamethrin toxicity to chlorophycea is unknown to date, the rise in IVF clearly not being linked to cell disruption and chlorophyll $a$ release in the medium but probably resulting from a modification of the PSII function (Seguin et al. 2002). Bacterial communities, used in this study as non target microorganisms, which hitherto have rarely been included in aquatic ecotoxicological studies, were shown to be sensitive to the two pesticides tested, especially paraquat. Depending on the endpoint chosen for assessing toxicity, the effects of paraquat were varied with a bacterial cell density remaining unaffected whereas cultivable bacteria and bacterial activity (estimated from ${ }^{3} \mathrm{H}$-thymidine incorporation rates) decreased significantly at a $4.4 \mu \mathrm{g} / \mathrm{L}$ concentration of paraquat in the medium. Our results suggest that the activity and viability endpoints provide a good proxy for metabolically active bacteria in the presence of pesticides. The influence of paraquat on nitrifying bacteria in aqueous systems has been studied by Gadkari (1998) which shows a complete inhibition of ammonium and nitrite oxidation pathways at low concentrations of paraquat $(1 \mu \mathrm{g} / \mathrm{L})$. Among the rare studies treating of interaction bacteria-pesticide, Knapp et al. (2005) showed a "topdown" effect of deltamethrin on natural microbial communities in outdoor mesoscoms, rather than the direct negative effect on bacteria as suggested in this study.

Concentrated extracts of water from Loumbila reservoir showed clear toxic effects for all types of microorganisms assayed. The two natural bacterial populations (from the Koubri and Bam reservoirs) responded in a similar way to the extract, with a marked negative effect on the bacterial abundance after 12 hours and 24 hours exposure. However, despite a decrease near zero for ${ }^{3} \mathrm{H}$ thymidine incorporation rates (activity), culturable bacteria showed a clear recovery after 24 hours, suggesting that a fraction of the bacterial populations was able to cope with the Loumbila extracts. This result was confirmed by flow cytometry analysis with the rise of a new bacterial population after 24 hours, with higher nucleic acid content and larger apparent size (FL1 and SSC curves in Fig. 5). The three different bacterial populations, dominant at the beginning of the experiment, were strongly affected by the toxicants during the twelve first hours of exposure with the disappearance of 3 groups compared to the controls owing to cell degradation. However, after 24 hours exposure, a distinct bacterial population appeared on the cytogram (Fig. 5C), suggesting either an adaptation and / or a selection of bacterial cells. A minor pre-existing bacterial consortium, tolerant to the toxicants, was selected by the toxicants in the Loumbila extract. This corroborates the hypothesis postulated by Lopez et al. (2005), in a study on biodegradation, that it is possible for a selection of a bacterial consortium to degrade and transform pesticides. Further experiments will be needed to determine more clearly the type of bacterial populations involved in this phenomenon using genetic and molecular approaches, since the effects of toxicants on natural competition between microorganisms could have relevant effects on ecosystemic functions.

The response of the cyanobacterium Cylindrospermopsis raciborskii to the extract could support several hypotheses with respect to the time evolved before measuring the toxicity endpoint. There was clearly a time-dependant reaction of $C$. raciborskii, with the dose-response curves similar for six and twenty-four hours of incubation. Significant changes in the IVF relative to the controls were observed after six hours exposure but changes in dose-response patterns were noticed after 24 hours. With Monoraphidium sp. cultures (results not shown), the Loumbila extract showed a different pattern of responses than those reported for C. raciborskii. The two concentrations 645 and 1020 $\mathrm{mL} / \mathrm{L}$ caused a significant decrease in IVF while the highest one $(2041 \mathrm{~mL} / \mathrm{L})$ resulted in a significant increase of IVF relative to the control. These response types were quite similar for measurements taken after 6 hours and 24 hours and a noticeable bleaching of the cultures was observed with the highest concentration after 24 hours. Our results suggest that one or several compounds in the Loumbila extracts are rapidly and lethally toxic to the cyanobacterium $C$. raciborskii, resulting in cell death and photosynthetic pigment release in the surroundings as visually observed. These effects were similar in appearance to the effects of paraquat on C. raciborskii after 18 hours and 40 hours exposure.

Zooplankton populations responded dramatically to the Loumbila extracts. The lowest concentration assayed during the acute toxicity tests $(64 \mathrm{~mL} / \mathrm{L})$ was fully lethal for the two species Diaphanosoma excisum and Moina micrura; however, in the chronic toxicity tests, only the $12.8 \mathrm{~mL} / \mathrm{L}$ dose was toxic to M. micrura. The effects of Loumbila extracts were similar to those observed with pure deltamethrin with the death of all the individuals exposed to the weakest effective concentration 
during acute tests, whereas the re-diluted samples resulted in a decrease in the M. micrura population growth rate.

The effects of the Loumbila extract on phytoplankton and zooplankton are similar to the combined effects of paraquat (on phytoplankton) and deltamethrin (on zooplankton). Despite the lack of chemical identification and quantification of compounds present in the extract using GC-MS and LC-MS (Dr. C. Mouvet, BRGM Orléans, personal communication), it is obvious that it contains a cocktail of pollutants and/or toxic natural compounds, affecting drastically the organisms living in the aquatic ecosystem. These results raise concerns about the actual chemical pressure exerted on these water bodies of Burkina Faso, taking in mind that contamination, if any, could be detrimental to sustaining aquatic life and economical values of these ecosystems, but also to human health.

\section{Conclusions}

This study was based on tropical planktonic microorganisms to assess successfully the ecotoxicological effects of known pesticides, and an unknown water extract. By using "local" organisms rather than "standardized" laboratory cultured organisms (such as Pseudokirchneriella subcapitata, Daphnia pulex, etc.) this study highlights the importance of experimental and local investigations to examine pesticide or unknown toxicant effects. Our results showed that both paraquat and deltamethrin were toxic to microalgae and zooplankton respectively, in accordance with the mode of action. Moreover, paraquat was significantly toxic to non target microorganisms as natural bacterioplankton. Toxicity testing of the Loumbila water extract resulted in apparent combination of effects - such as ones observed with paraquat (herbicide) and deltamethrin (insecticide) - on phytoplankton and zooplankton from surrounding areas. These effects were not supported by analytical detection and quantification of any pesticide among a list of 80 searched for (not shown), and the precise nature of toxic compounds in the extracts is still unknown. Nevertheless, the approach reported here can be considered as a step towards making studies ecologically relevant (Lahr et al. 2000, Lopes et al. 2007), as part of the concern for regional testing programs in the tropics (Wiktelius et al. 1999). Effort will be pursued to enhance knowledge about sensitivity of tropical aquatic organisms, relative to their temperate counterparts. This will improve environmental assessments in the tropics as the organisms used to assess toxic effects would be those that are exposed to contamination in the field, or their close ecological and phylogenetic relatives. Furthermore, this could lead to more specific studies for individual freshwater bodies in West African countries, which are poorly known regarding the concern of environmental assessment.

\section{Acknowledgements}

This work is part of the IRD UR 167 Cyroco research program. Field sampling have been valuably facilitated by the enthusiastic help of Nicolas Augis, and the support of Auberge Les Bougainvilliers staff and direction in Koubri, Burkina Faso. Maïmouna M'Boup and El Hadj N'Dour (IRD Dakar) are warmly acknowledged for their contributions to laboratory analysis of bacterial samples and field zooplankton experiments respectively. Dr. Christophe Mouvet (BRGM Orléans) is acknowledged for pesticide analysis of water extract. Financial support was partly provided by the Small Reservoir Project of the Challenge Program on Water and Food (Colombo, Sri Lanka), and the French Ministry for Ecology and Sustainable Management and Development (ECOMET, grant CV070000783 ). Cultures of microalgae were kindly supplied by Prof. Cécile Bernard, MNHN, Paris. Anonymous referees are acknowledged for improvement on this manuscript.

\section{References}

Alberdi JL, Sáenz ME, Di Marzio WD, Tortorelli MC (1996) Comparative acute toxicity of two herbicides, paraquat and glyphosate, to Daphnia magna and D. spinulata. Bull Environ Contam Toxicol 57:229-235

Baun A, Bussarawit N, Niholm N (1998) Screening of pesticide toxicity in surface water from an agricultural area at Phuket Island (Thailand). Environ Poll 102:185-190

Berger C, Ba N, Gugger M, Bouvy M, Rusconi P, Couté A, Trousselier M, Bernard C (2006) Seasonal dynamics and toxicity of Cylindrospermopsis raciborskii in Lake Guiers (Senegal, West Africa). FEMS Micobiol Ecol 57:355-366

Bouvy M, Troussellier M, Got P, Arfi R (2004) Bacterioplankton responses to bottom-up and topdown controls in a West African reservoir (Sélingué, Mali). Aquat Microb Ecol 34:301-307 
Bouvy M, Ba N, Ka S, Sane S, Pagano M, Arfi R (2006) Phytoplankton community structure and species assemblage succession in a shallow tropical lake (Lake Guiers, Senegal, West Africa). Aquat Microb Ecol 45:147-161

Briand JF, Leboulanger C, Humbert JF, Bernard C, Dufour P (2004) Cylindrospermopsis raciborskii (Cyanobacteria) invasion at mid-latitudes: selection, wide physiological tolerance, or global warming ? J Phycol 40:231-238

Chapman PM, McDonald BG, Kickham PE, McKinnon S (2006) Global geographic differences in marine metals toxicity. Mar Poll Bull 52:10811084

Christensen AM, Nakajima F, Baun A (2006) Toxicity of water and sediment in a small urban river (Store Vejleå, Denmark). Environ Poll 144:621-625

Conley DJ (1999) Biogeochemical nutrient cycles and nutrient management strategies. Hydrobiologia 410:87-96

Gadkari D (1998) Effects of atrazine and paraquat on nitrifying bacteria. Arch Environ Contam Toxicol 17:443-447

Gagneten AM (2002) Effects of paraquat herbicide on zooplankton. Iheringia, Serie Zoologia 92:47-56 (in Spanish)

Hammer $\varnothing$, Harper DAT (2005) Paleontological software PAST, version 1.32, http://folk.uio.no/ohammer/past

Hengel MJ, Mourer CR, Shibamoto T (1997) New Method for Analysis of pyrethroid insecticides: esfenvalerate, cis-permethrin, and trans-permethrin, in surface waters using solid-phase extraction and gas chromatography. Bull Environ Contam Toxicol 59:171-178.

Knapp CW, Caquet T, Hanson ML, Lagadic L, Graham DW (2005) Response of water column microbial communities to sudden exposure to deltamethrin in aquatic mesocosms. FEMS Microbiol Ecol 54:157-165

Lahr J, Diallo AO, Gadji B, Diouf PS, Bedaux JJM, Badji A, Ndour KB, Andreasen JE, van Straalen NM 2000. Ecological effects of experimental insecticide applications on invertebrates in Sahelian temporary ponds. Environ Toxicol Chem 19:12781289

Leboulanger C, Quiblier C, Dufour P. 2006. Rapid assessment of multiple-limiting factors of phytoplankton biomass: bioassays, in vivo chlorophyll- $a$ fluorescence, and factorial design. Arch Hydrobiol 166:433-451

Lopes I, Moreira-Santos M, da Silva EM, Sousa JP, Guilhermino L, Soares AMVM, Ribeiro R (2007) In situ assays with tropical cladocerans to evaluate edge-of-field pesticide runoff toxicity. Chemosphere 67: 2250-2256

Lopez L, Pozo C, Rodelas B, Calvo C, Juarez B, Martinez-Toledo MV, Gonzalez-Lopez J (2005) Identification of bacteria isolated from oligotrophic lake with pesticide removal capacities. Ecotoxicology 14:299-312

Lürling M, Roessink I (2006) On the way to cyanobacterial blooms: Impact of the herbicide metribuzin on the competition between a green alga (Scenedesmus) and a cyanobacterium (Microcystis). Chemosphere 65:618-626

Marie D, Partensky F, Jacquet S, Vaulot D (1997) Enumeration and cell cycle analysis of natural populations of marine picoplankton by flow cytometry analysis using the nucleic acid stain SYBR green I. Appl Environ Microbiol 63:186-193 Nicholson PS, Hirsch PR (1998) The effects of pesticides on the diversity of culturable soil bacteria. J Appl Microbiol 4:551-558

Ntow WJ (2001) Organochlorine pesticides in water, sediment, crops and human fluids in a farming community in Ghana. Arch Environ Contam Toxicol 40:557-563

Ntow WJ (2005) Pesticide residues in Volta Lake, Ghana. Lake Reserv Res Manag 10:243-248

Nunez O, Moyano E, Galceran T (2002) Solidphase extraction and sample stacking - capillary electrophoresis for the determination of quaternary ammonium herbicides in drinking water. $\mathbf{J}$ Chromatogr A 946:275-282

Osafo S, Frempong E (1998) Lindane and endosulfan residues in water and fish in the Ashanti region of Ghana. J Ghana Sci Assoc 1:135-140

Paerl HW (1997) Coastal eutrophication and harmful algal blooms: Importance of atmospheric deposition and groundwater as "new" nitrogen and other nutrient sources. Limnol Oceanogr 45:11541165

Paerl HW, Dyble J, Moisander PH, Noble RT, Piehler MF, Pinckney JL, Steppe TF, Twomey L, Valdes LM (2003) Microbial indicators of aquatic ecosystem change: current applications to eutrophication studies. FEMS Microbiol Ecol 46:233-24

Pagano M, Saint-Jean L, Arfi R, Bouvy M, Shep H (2000) Population growth capacities and regulatory factors in monospecific cultures of the cladocerans Moina micrura and Diaphanosoma excisum and the copepod Thermocyclops decipiens from Côte d'Ivoire (West Africa). Aquat Living Res 13:163172

Perschbacher PW, Ludwig GM (2004) Effects of diuron and other aerially applied cotton herbicides and defoliants on the plankton communities of aquaculture ponds. Aquaculture 233:197-203

Porter KG, Feig YS (1980) The use of DAPI for identifying and counting aquatic microflora. Limnol Oceanogr 25:943-948

Relyea RA (2005) The impact of insecticides and herbicides on the biodiversity and productivity of aquatic communities Ecol Appl 15:618-627

Ross C, Santiago-Vazquez L, Paul V (2006) Toxin release in response to oxidative stress and 
programmed cell death in the cyanobacterium Microcystis aeruginosa. Aquatic Toxicol 78:66-73 Sáenz ME, Alberdi JL, Di Marzio WD, Accorinti J, Tortorelli MC (1997) Paraquat toxicity to different green algae. Bull Environ Contam Toxicol 58:922928

Seguin F, Le Bihan F, Leboulanger C, Bérard A (2002) A risk assessment of pollution: induction of atrazine tolerance in phytoplankton communities in freshwater outdoor mesocosms, using chlorophyll fluorescence as an endpoint. Water Res 36:32273236

Troussellier M, Courties C, Lebaron P, Servais P (1999) Flow cytometric discrimination of bacterial populations in seawater based on SYTO 13 staining of nucleic acids. FEMS Microbiol Ecol 29 4: 319330

Wiktelius S, Chiverton PA, Meguenni H, Bennaceur M, Ghezal F, Umeh EDN, Egwuatu RI, Minja E, Makusi R, Tukahirwa E, Tinzaara W,
Deedat Y (1999) Effects of insecticides on nontarget organisms in African agroecosystems: a case for establishing regional testing programmes. Agr Ecosyst Environ 75:121-131

Wilhelm C, Conrad R, Meitzler L, Muhlenweg A (1996) Combination of solid phase extraction and a microalgal test system based on pulse-amplitude modulated fluorescence to detect photosystem II herbicides up to $0.05 \mu \mathrm{eq} \mathrm{l}^{-1}$. J Appl Phycol 8:171173

Wong PK (2000) Effects of 2,4-D, glyphosate and paraquat on growth, photosynthesis and chlorophyll a synthesis of Scenedesmus quadricauda Berb 614. Chemosphere 41:177-182

Xue N, Zhang D, Xu X (2006) Organochlorinated pesticide multiresidues in surface sediments from Beijing Guanting reservoir. Water Res 40:183-194 
Table 1: Main environmental parameters and physico-chemical characteristics of the three reservoirs studied in May 2005 (one sample per reservoir, taken at the central station). Temp: temperature; SRP: soluble reactive phosphorus.

\begin{tabular}{|c|c|c|c|c|c|c|c|c|c|c|c|c|}
\hline & $\begin{array}{l}\text { Basin } \\
\text { population } \\
(2004)\end{array}$ & $\begin{array}{l}\max . \\
\text { volume } \\
\left(M m^{3}\right)\end{array}$ & $\begin{array}{l}\max . \\
\text { depth } \\
(\mathrm{cm})\end{array}$ & $p H$ & $\begin{array}{l}\text { conductivity } \\
(\mu \mathrm{S} / \mathrm{cm})\end{array}$ & $\begin{array}{l}\text { Secchi } \\
\text { depth } \\
(\mathrm{cm})\end{array}$ & $\begin{array}{l}{\left[\mathrm{O}_{2}\right]} \\
(\mathrm{mg} / \mathrm{L})\end{array}$ & $\begin{array}{l}\text { Temp } \\
{ }^{\circ} \mathrm{C}\end{array}$ & $\begin{array}{l}\text { Sestonic } \\
\text { load } \\
(\mathrm{mg} / \mathrm{L})\end{array}$ & $\begin{array}{l}S R P \\
(\mu M)\end{array}$ & $\begin{array}{l}\mathrm{NH}_{4}^{+} \\
(\mu M)\end{array}$ & $\begin{array}{l}\operatorname{chl} \text { a } \\
(\mu g / L)\end{array}$ \\
\hline Loumbila ${ }^{*}$ & 27964 & 43.0 & 360 & 6.82 & 61.9 & 15.5 & 6.5 & 28.4 & 58.4 & 1.42 & 3.5 & 9.59 \\
\hline $\mathrm{Bam}^{\#, \S}$ & 62347 & 31.0 & 210 & 7.12 & 85.8 & 59 & 7.3 & 27.3 & 18.0 & 0.10 & 3.2 & 18.64 \\
\hline Koubri $^{\#, £}$ & 43750 & 3.5 & 130 & 6.90 & 81.7 & 63.5 & 7.2 & 30.4 & 17.3 & 0.04 & 0.7 & 14.51 \\
\hline
\end{tabular}

*: reservoir sampled for extraction and concentration of putative toxic compounds.

\#: reservoirs sampled for bacterial populations used in ecotoxicological tests.

$\S$ : reservoir from which Monoraphidium sp. was isolated.

$£$ : reservoir from which zooplankton test organisms were isolated.

Table 2. Concentration of toxicants (reservoir extracts and pure pesticides) assayed on the planktonic microorganisms during this study. used concentration during the test

\begin{tabular}{lllllll}
\hline extracts & $\mathrm{mL} / \mathrm{L}$ & & & & & \\
\hline Loumbila & 0 & $64.5^{\mathrm{a}}$ & $102^{\mathrm{b}}$ & $645^{\mathrm{a}}$ & $1020^{\mathrm{b}}$ & $2041^{\mathrm{a}}$ \\
& & $3.2^{\mathrm{c}}$ & $12.8^{\mathrm{c}}$ & $32^{\mathrm{c}}$ & & $6123^{\mathrm{d}}$ \\
pure pesticides & $\mu \mathrm{g} / \mathrm{L}$ & & & & & \\
\hline Paraquat & 0 & $5.7^{\mathrm{a}}$ & $18.3^{\mathrm{b}}$ & $57.8^{\mathrm{a}}$ & $183^{\mathrm{b}}$ & $578^{\mathrm{a}}$ \\
& & $1.2^{\mathrm{c}}$ & $2.9^{\mathrm{c}}$ & $4.6^{\mathrm{c}}$ & & \\
Deltamethrin & 0 & $4.4^{\mathrm{a}}$ & $14.0^{\mathrm{b}}$ & $44.3^{\mathrm{a}}$ & $140^{\mathrm{b}}$ & $443^{\mathrm{a}}$ \\
& & $0.22^{\mathrm{c}}$ & $0.89^{\mathrm{c}}$ & $2.21^{\mathrm{c}}$ & & \\
methanol content $(\% \mathrm{v} / \mathrm{v})$ & 0.05 & & & & &
\end{tabular}

a: tested on all organisms; b: tested only on phytoplankton cultures; c: tested only on zooplankton during chronic toxicity assessment; d: tested only on natural bacterioplankton of Koubri and Bam reservoirs.

Table 3. Reported LOECs (lowest concentrations resulting in significant effects relative to controls) in $\mu \mathrm{g} / \mathrm{L}$ for short-term effects of paraquat and deltamethrin on the planktonic microorganisms during this study. n.e.o.: no effect observed. *: maximal concentration assayed was $4.6 \mu \mathrm{g} / \mathrm{L}$.

\begin{tabular}{|c|c|c|c|c|c|c|c|c|c|c|}
\hline endpoint & $\begin{array}{l}\text { bacteriop } \\
\text { bacterial } \\
\text { density }\end{array}$ & $\mathrm{n}(12 \mathrm{~h})$ & $\begin{array}{l}\text { thymidine } \\
\text { incorporation }\end{array}$ & C. racib & IVF $40 \mathrm{~h}$ & Monoral & hidium sp. & M. micru & growth & $\begin{array}{l}\text { D. excisum } \\
\text { survival }\end{array}$ \\
\hline paraquat & 577 & 57.7 & 5.7 & 183 & 57.8 & 57.8 & 578 & 577 & n.e.o.* & 57.7 \\
\hline deltamethrin & 4.4 & 4.4 & 4.4 & n.e.o. & n.e.o. & n.e.o. & 443 & 4.4 & 2.21 & 4.4 \\
\hline
\end{tabular}

\section{Figure captions}

Figure 1: Effects of paraquat and deltamethrin on bacterioplankton isolated from the Koubri reservoir. A and B: effects of paraquat and deltamethrin respectively, on mean and SD of cell density. Black bars: initial densities $(0$ h); light grey: after $12 \mathrm{~h}$ incubation; dark grey: after $24 \mathrm{~h}$ of incubation. Effects of paraquat (C) and deltamethrin (D) on mean and SD of cultivable bacteria density expressed as colony forming units (CFU). Black bars: initial CFUs $(0 \mathrm{~h})$; light grey: after $12 \mathrm{~h}$ incubation; dark grey: after $24 \mathrm{~h}$ of incubation. Effects of paraquat $(\mathrm{E})$ and deltamethrin (F) on mean and SD of bacterial activity expressed as ${ }^{3} \mathrm{H}$-thymidine incorporation rate (pmol/L/h). Black bars: initial activities $(0 \mathrm{~h})$; light grey: after $12 \mathrm{~h}$ incubation; dark grey: after $24 \mathrm{~h}$ of incubation.

Figure 2: Effects of pure pesticides on in vivo fluorescence (IVF) of Monoraphidium sp. (open circles) and Cylindrospermopsis raciborskii (closed circles). Results are expressed as a function of incubation time (A: $6 \mathrm{~h}$ and B: $40 \mathrm{~h}$ for paraquat; $\mathrm{C}: 6 \mathrm{~h}$ and $\mathrm{D}$ : $40 \mathrm{~h}$ for deltamethrin) and significant changes relative to control are marked with asterisks $(*=5 \%$ confidence level; $* *=1 \%$ confidence level).

Figure 3: Acute toxic effects of paraquat (A, B) and deltamethrin (C, D) on Diaphanosoma excisum (A, C) and Moina micrura (B, D) survival after 24 (open circles) and $48 \mathrm{~h}$ incubation (closed circles). Significant changes 
relative to control are marked with asterisks $(*=5 \%$ confidence level; $* *=1 \%$ confidence level). Chronic toxic effects of paraquat (E) and deltamethrin (F) on Moina micrura growth rate after five days of incubation. Significant changes relative to control are marked with asterisks $(*=5 \%$ confidence level; $* *=1 \%$ confidence level).

Figure 4: Effects of extracts from Loumbila ("Test") on mean and SD of bacterial abundance (A, D), cultivability $(\mathrm{B}, \mathrm{E})$, and activity $(\mathrm{C}, \mathrm{F})$, of natural bacterioplankton isolated from reservoirs of Koubri (upper panel) and Bam (lower panel), compare to control without extract additions. Black bars: initial values (0 h); light grey: after $12 \mathrm{~h}$ incubation; dark grey: after $24 \mathrm{~h}$ of incubation.

Figure 5: Example of cytogram obtained on bacterial communities exposed to Loumbila extract at the beginning of exposure (A), and after $12 \mathrm{~h}(\mathrm{~B})$ and $24 \mathrm{~h}$ incubation (C). Fluorescence intensity of stained DNA (FL1 channel) and apparent size (SSC channel) standards are represented by calibrated beads of 1 and $2 \mu \mathrm{m}$ diameter, whereas a quantitative standard (TrueCount TC) allowed precise determination of sample volume, thus bacterial density in the analyzed sample.

Figure 6: Effects of Loumbila extracts on in vivo fluorescence (IVF) of Cylindrospermopsis raciborskii (closed circles). Results are expressed as a function of incubation time (6 and $24 \mathrm{~h})$ and significant changes relative to control are marked with asterisks $(*=5 \%$ confidence level; $* *=1 \%$ confidence level).

Figure 7: Acute toxic effects of Loumbila extracts on Diaphanosoma excisum (A) and Moina micrura (B) survival after $24 \mathrm{~h}$ incubation (open circles). C: chronic toxic effects of Loumbila extracts on Moina micrura growth rate after five days of incubation. Significant changes relative to control are marked with asterisks $(* * *=$ $0.1 \%$ confidence level). 
Figure 1
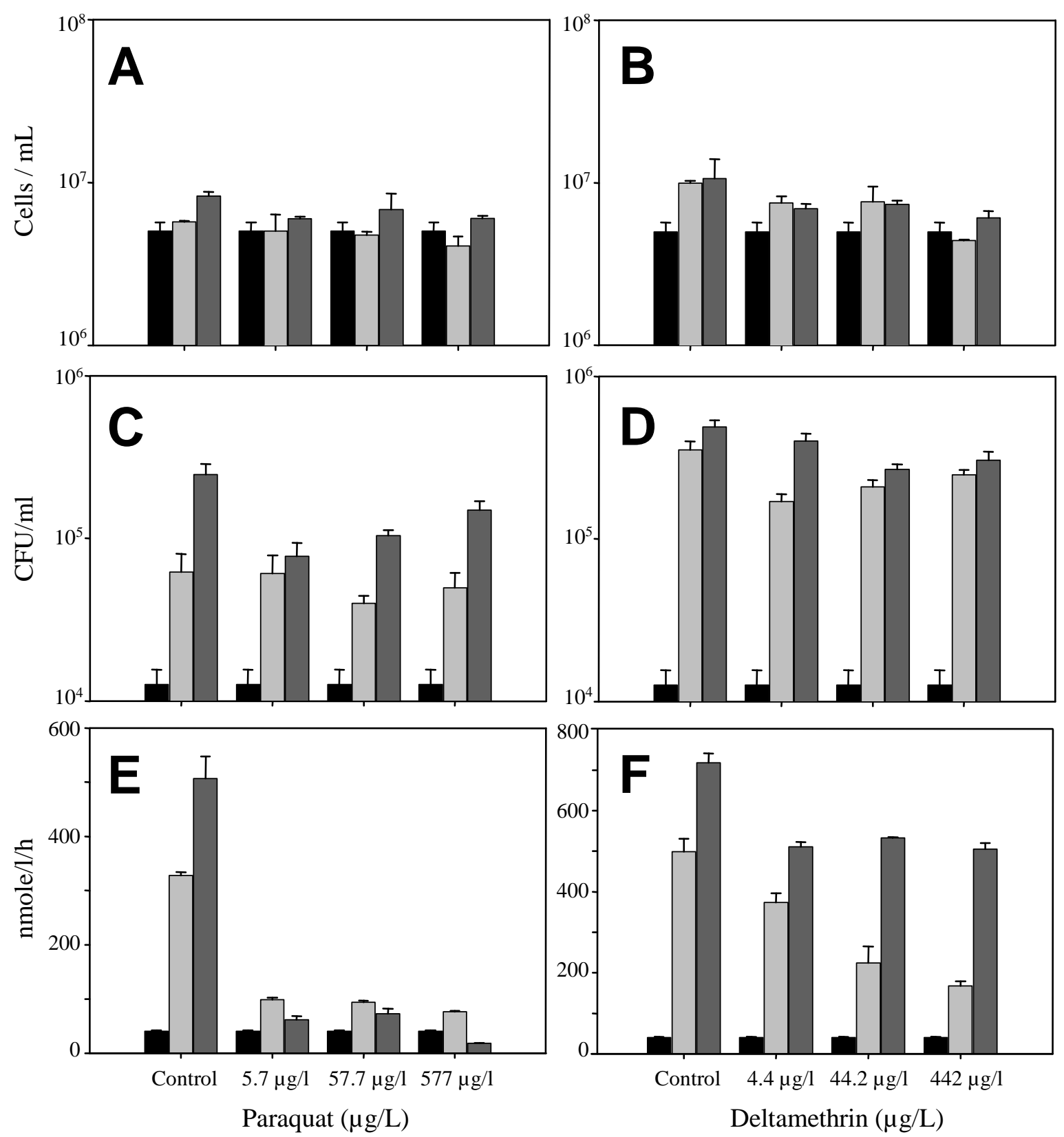
Figure 2
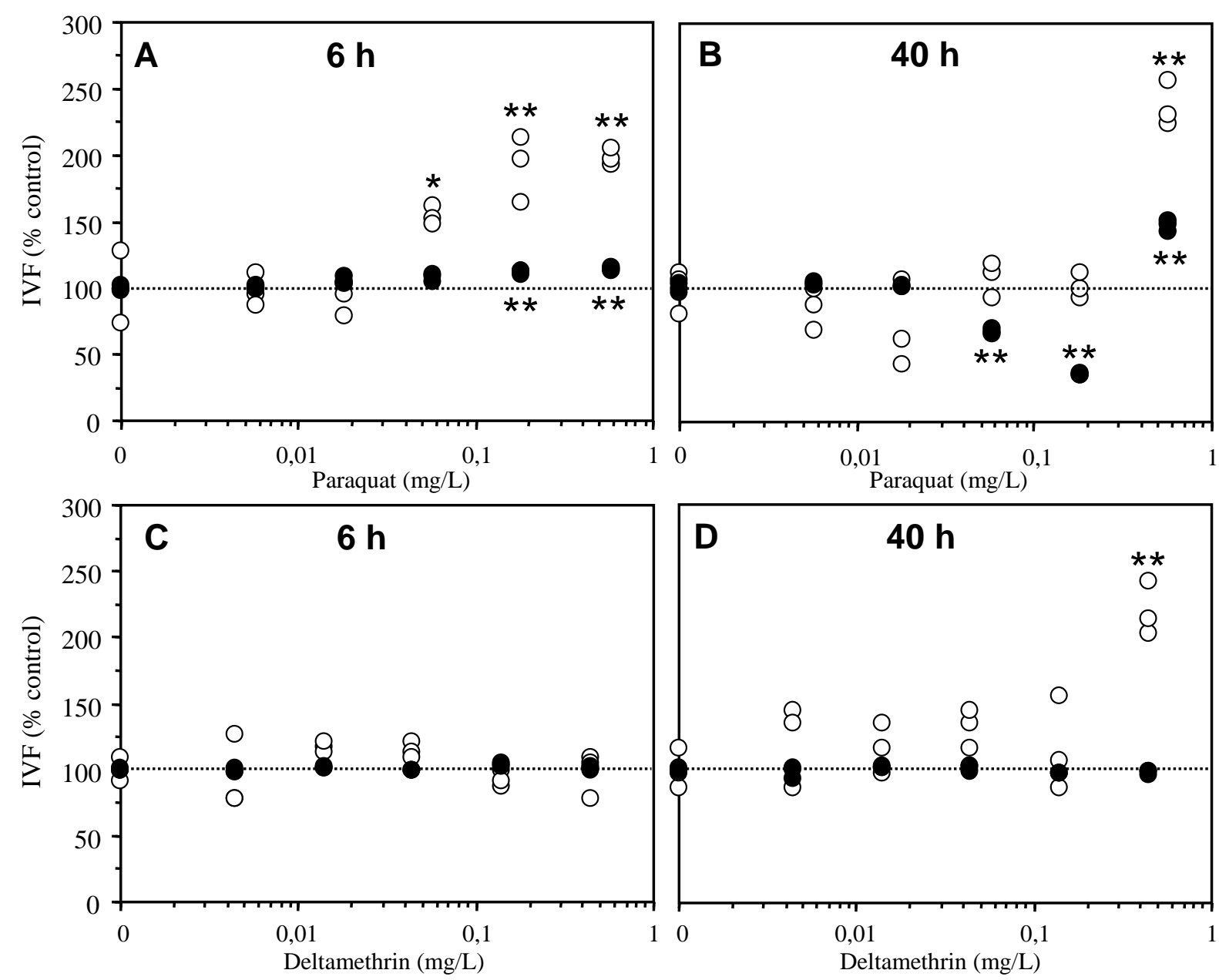


\section{Figure 3}
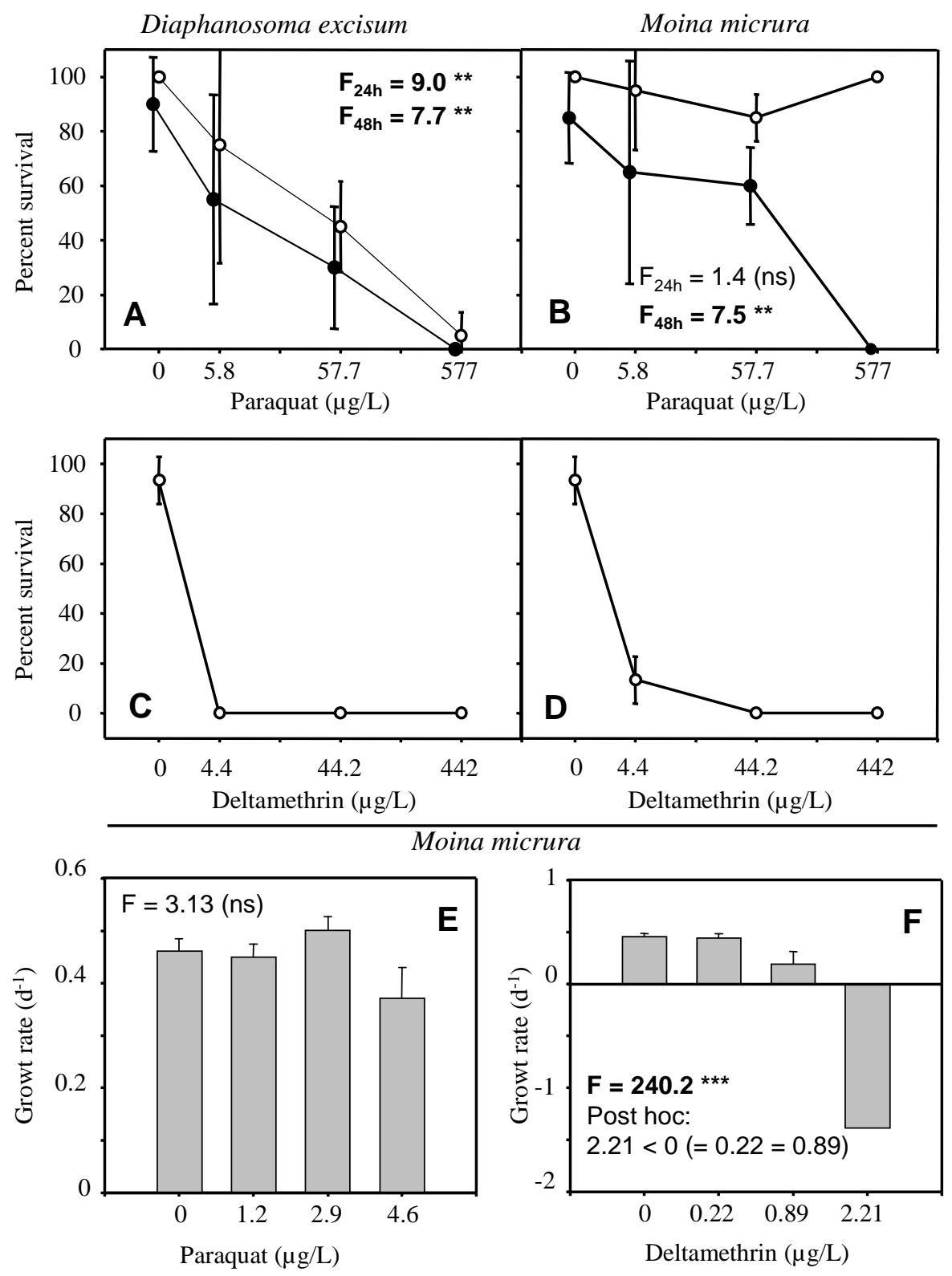

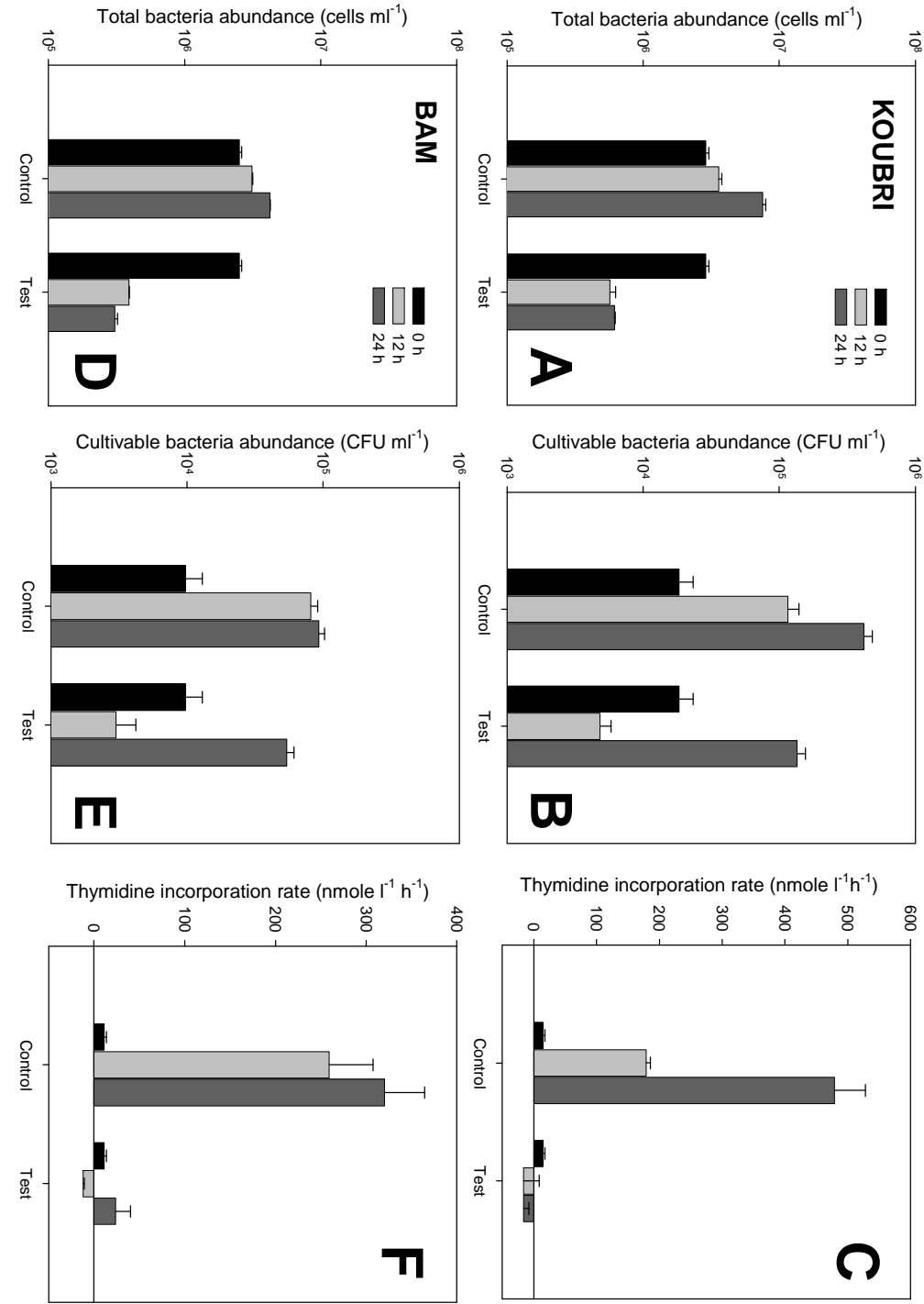
Figure 5
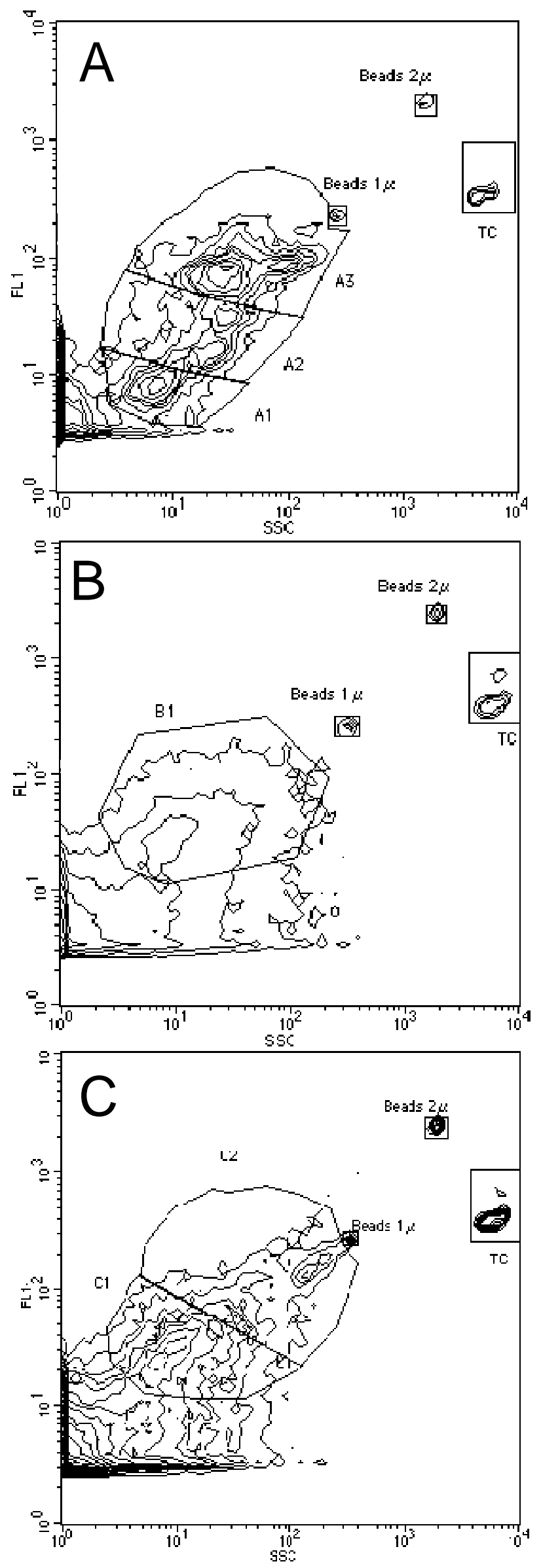
Figure 6

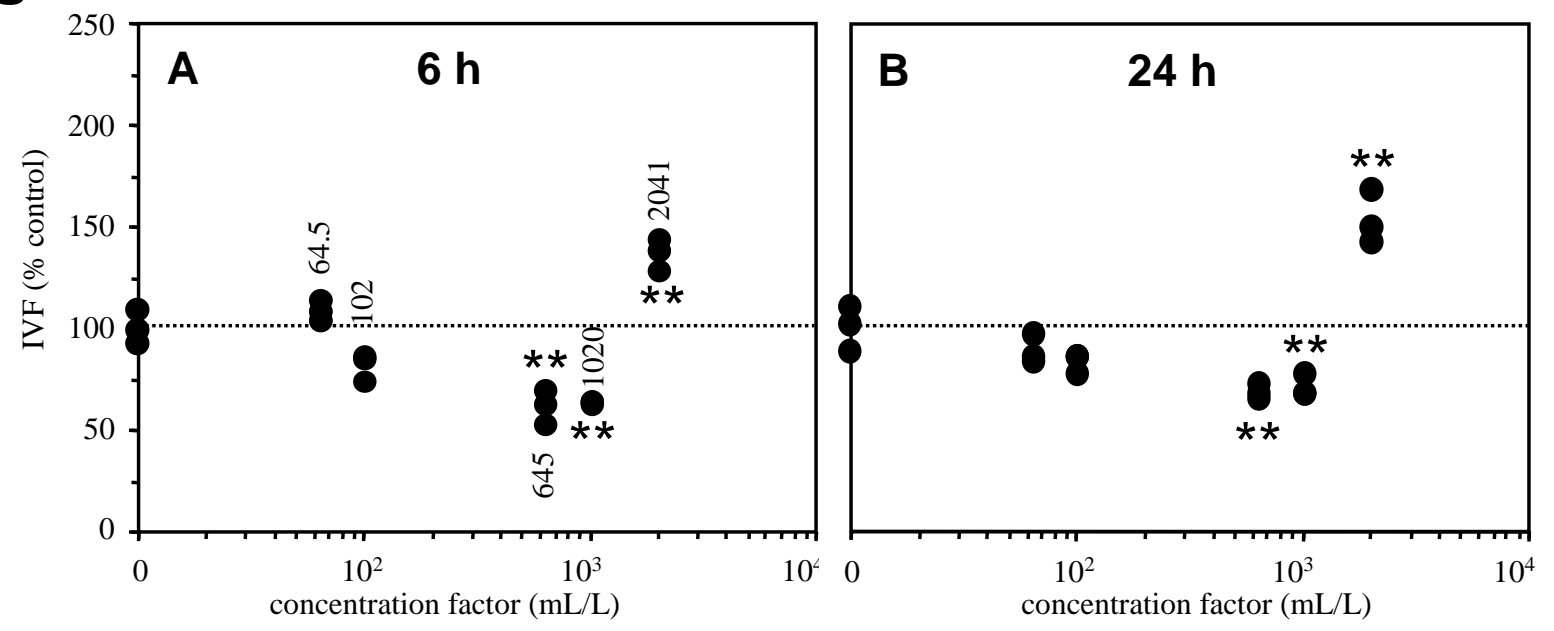

Figure 7
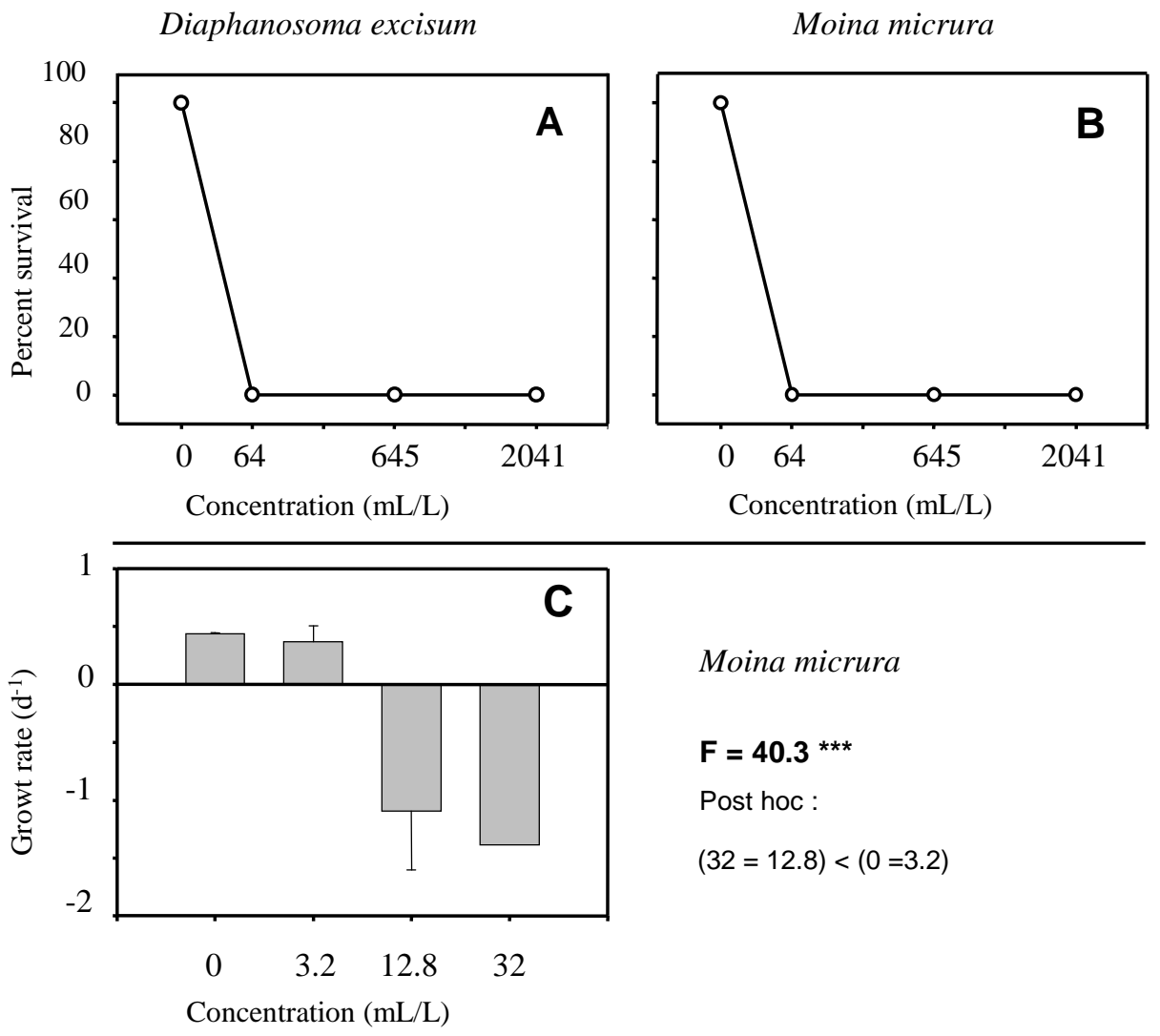

Moina micrura

$F=40.3^{\text {***}}$

Post hoc:

$(32=12.8)<(0=3.2)$ 